\title{
Formulation, Development, and Characterization of Lyophilized Para-Amino Salicylate Sodium Injection for an Effective Treatment for Multi-Drug Resistance-Tuberculosis
}

\author{
Mukhopadhyay Sayantan $^{1 *}$, Shivanand ${ }^{1}$ \\ ${ }^{1}$ Division of Pharmaceutical Sciences S.G.R.R.I.T.S, Patel Nagar Dehradun \\ Uttarakhand 248001, India.
}

\begin{abstract}
The purpose of this study was to the development and manufacture of stable lyophilized injection formulation of Para-Amino Salicylate sodium, a drug that used in the treatment of multi-drug resistance tuberculosis. The drug was unstable in the aqueous solution and it shows high impurity level. Lyophilization technique in the pharmaceutical industries used in the formulation of thermolabile and moisture sensitive drug. For the formulation purpose, initial drug-excipients compatibility study was conducted and on the basis of percentage impurity level, present excipients were selected. Drug- Excipients compatibility study result shows that sodium metabisulphite increases the percentage of impurity level found that $0.12 \%, 0.15 \%, 0.06 \%, 0.09 \%$, where the composition of API with sodium sulphite and other excipients reduces the impurities level. For the development of an effective formulation that provides stable, less impure and improved physicochemical characteristic of the model, several formulation methodologies were adopted.Compatibility study with reconstitution fluids was conducted for formulation (F-I, \& F-II), the result shows that reconstitution with $0.9 \%$ Sodium chloride\& $5 \%$ Dextrose injections, the reconstituted solution becomes hypertonic, where water for injection gives an isotonic solution. Accelerated stability perusal result for related substance during time period of initial to $6^{\text {th }}$ month stability result indicates formulation (F-I, 0.05\%, 0.13\%), (F-II, 0.08\%, 0.16\%), and assay percentage (F-I, 102.14\%, 98.61\%), (F-II, 100.49\%, 96.27\%). Related substance (impurity) and Assay result indicate that formulation F-I shows less impurity level and high assay percentage as compared to formulation F-II. Accelerated stability $6^{\text {th }}$-month result indicates that Para-Amino Salicylate Sodium lyophilized injection found to be physically and chemically stable.
\end{abstract}

Keywords: Lyophilized, Para-Amino Salicylate sodium, Thermolabile, Hypertonic, Isotonic.

\section{Introduction}

Tuberculosis is one of the major health problems worldwide. According to the World Health Organisation (WHO) approximately death 5,000 people per day ubiquitously, the world due to tuberculosis\& it 
is a single treatable infectious disease. In 2008 approximately death due to tuberculosis is 1.8 million that is reported by The World Health Organisation (WHO) ${ }^{\mathbf{1}, 2}$. Causing agent of tuberculosis isMycobacterium tuberculosis, which is airborne.During the active stage, TB is highly contagious disease and it can be generating by inhaling the airborne particles of M. tuberculosis,

Para-aminosalicylic acid is a second line drug effectively used in the treatment of multi-drug resistance tuberculosis. It is aclinically introduced in the 1940sand used in the treatment of tuberculosis into the 1960s. Para-aminosalicylic acid is a bacteriostatic chemotherapeutic agent used in the treatment of all types of tuberculosis, in extrapulmonary and pulmonary. Chemically it is (4-Amino-2-hydroxybenzoic acid).Paraaminosalicylic acid is a white or almost white crystalline powder ${ }^{5}$. A daily dose of para-aminosalicylic acid is 10-15g for adult and children and older than 14 years, recommended by the German Bundesanzeiger and the guidelines of the German central committee. The parenteral dosage of para-aminosalicylic acid is administered by intravenously with $500 \mathrm{ml}$ of reconstituted sterile water for injections.Para-aminosalicylic acid is get degraded due to thepresence of impurity m-aminophenol, and it containhigh moisture content about 16-18\% ${ }^{6,7}$.

The active pharmaceutical ingredient that isthermolabile and moisture sensitive in nature generally degraded in atmospheric condition and thus have reduced stability and self-life. Lyophilization is the most common technique for the manufacturing of parenteral pharmaceutical product when the product is unstable in aqueous solution. It helps in improving the stability and self-life of a pharmaceutical product.Lyophilization technique mainly involved in the removal of moisture content from the pharmaceutical product. In this process, thefirst Solvent is in a frozen state and then water is removed by the process of sublimation ${ }^{8,9}$. The Lyophilization technique mainly involved, freezing formation of ice crystal, primary drying removal of unbound water content from the drug product by the process of sublimation, and secondary drying removal ofbound water which present in a very less amount of moisture content in the primary drying and make the final product stable ${ }^{10,11}$.

\section{Experimental}

\section{Materials}

Sodium Aminosalicylatedihydrate was procured from Rusan Pharma Ltd. All other chemicals and reagents used were analytical grades such as Sodium Chloride, Disodium Edetate, Sodium Sulphite, Sodium Metabisulphite, Sodium Hydroxide and sterile water for injection.

\section{Methods}

\section{Preformulation study regarding formulation development}

\section{Drug- Excipients compatibility study ${ }^{12,13,14}$}

Compatibility study carried out for the selection of suitable excipients for the development of stable and robust lyophilized formulation. Compatibility study of Para-Aminosalicylate sodium drug substances with various excipients was carried out. To separately prepare a solution of each excipient with API based on thesuitable ratio, each excipient plays an important role in the formulation. Each separately prepared solution to be filled in aseparate glass vial and charged in the stability chamber at condition $40^{\circ} \pm 2^{\circ} \mathrm{C} / 75 \% \mathrm{RH} \pm 5 \% \mathrm{RH}$ and $25^{\circ} \pm 2^{\circ} \mathrm{C} / 60 \% \mathrm{RH} \pm 5 \% \mathrm{RH}$ for the time period of 15 days and 1 month respectively. Analysis result for related substances during compatibility studies are recorded.

\section{Order of addition drug-excipient study}

From the various literature study, it is clear that thePara-Amino Salicylate Sodium shows more stable impurity profile in basic $\mathrm{pH}$.In order to establish the desired $\mathrm{pH}$, order of addition of excipients and drug, the following of experiments were performed.

\section{Method. A}

Direct addition of all excipients in water for injection Followed by Para-Amino Salicylate Sodium\& pH adjustment with $1 \mathrm{M} \mathrm{NaOH}$ Solution. 
- Step 1. Weighed quantity of Sodium sulphitewas dissolved into $70 \%$ of water for injection with continuous stirring.

- $\quad$ Step 2. Weighed quantity of Disodium EDTAwas dissolved, to the solution of step 1. with continuous stirring.

- $\quad$ Step 3. Weighed quantity of Sodium chloridewas dissolved, to the solution of step 2.with continuous stirring and check the solution $\mathrm{pH}$.

- $\quad$ Step 4. Weighed quantity of Para-Amino Salicylate Sodium was dissolved, to the solution of step 3. with continuous stirring.

- $\quad$ Step 5. Adjust the $\mathrm{pH}$ of the solution to $6.5 \pm 0.1$ with $1 \mathrm{M} \mathrm{NaOH}$ solution at step 4 .

- $\quad$ Step 6. Finally make up the volume with WFI, with continuous stirring to get a uniform solution.

\section{Method. B}

Adjust the $\mathrm{pH}$ of the solution before addition of Disodium EDTA \&Para-Amino Salicylate Sodium Followed by $\mathrm{pH}$ adjustment with $1 \mathrm{M} \mathrm{NaOH}$ Solution

- Step 1. Weighed quantity of Sodium sulphitewas dissolved into $70 \%$ of water for injection with continuous stirring.

- $\quad$ Step 2. Adjust $\mathrm{pH}$ of the solution to $6.5-7.0$ with $1 \mathrm{M} \mathrm{NaOH}$ solution at step 1. with continuous stirring.

- Step 3. Weighed quantity of Disodium EDTA was dissolved, to the solution of step 2. with continuous stirring and check the solution $\mathrm{pH}$.

- Step 4. Weighed quantity of Para-Amino Salicylate Sodium was dissolved, to the solution of step 3. with continuous stirring.

- Step 5. Weighed quantity of Sodium chloridewas dissolved, to the solution of step 4.with continuous stirring.

- $\quad$ Step 6. Adjust the $\mathrm{pH}$ of the solution to $6.5 \pm 0.1$ with $1 \mathrm{M} \mathrm{NaOH}$ solution at step 5.with continuous stirring.

- Step 7. Finally make up the volume with WFI, with continuous stirring to get a uniform solution.

\section{Method. C}

Addition of Sodium Hydroxide followed by addition of Disodium EDTA, Sodium sulphite\&ParaAmino Salicylate Sodium

- Step 1. Weighed quantity of Sodium Hydroxide was dissolved into $70 \%$ of water for injection with continuous stirring.

- $\quad$ Step 2. Weighed quantity of Disodium EDTA was dissolved, to the solution of step 1. with continuous stirring.

- $\quad$ Step 3. Weighed quantity of Sodium sulphitewas dissolved, to the solution of step 2. with continuous stirring and check the solution $\mathrm{pH}$.

- Step 4. Weighed quantity of Para-Amino Salicylate Sodium was dissolved, to the solution of step 3. with continuous stirring.

- Step 5.Weighed quantity of Sodium chloridewas dissolved, to the solution of step 4.with continuous stirring.

- Step 6. If required, adjust the $\mathrm{pH}$ of the solution to $6.5 \pm 0.1$ with $1 \mathrm{M} \mathrm{NaOH}$ solution at step 5.with continuous stirring.

- Step 7.finally make up the volume with WFI, with continuous stirring to get a uniform solution.

\section{Formulation development}

\section{PreparationPara-Amino Salicylate Sodium solution}

From the aboveperformed Order of addition experiment Method, C. was selected for the development of thelyophilized product. Preparation of thebulk solution.

- About $70 \%$ of the required batch quantity of Water for Injection (WFI) is taken in a jacketed stainless-steel formulation vessel and bring the temperature down to $40^{\circ} \mathrm{C}$, by Nitrogen purging for removing of dissolved oxygen. 
- Step 1. Weighed quantity of Sodium Hydroxide was dissolved into $70 \%$ of water for injection with continuous stirring.

- $\quad$ Step 2. Weighed quantity of Disodium EDTA was dissolved, to the solution of step 1. with continuous stirring.

- Step 3. Weighed quantity of Sodium sulphitewas dissolved, to the solution of step 2. with continuous stirring.

- $\quad$ Step 4. Weighed quantity of Para-Amino Salicylate Sodium was dissolved, to the solution of step 3. with continuous stirring.

- Step 5. Weighed quantity of Sodium chloride was dissolved, to the solution of step 4. with continuous stirring.

- $\quad$ Step 6. Adjust the $\mathrm{pH}$ of the solution to $6.5 \pm 0.1$ with $1 \mathrm{M} \mathrm{NaOH}$ solution at step 5. with continuous stirring.

- Step 7. finally make up the volume with WFI, with continuous stirring to get a uniform solution.

- After volume make-up, the bulk solution is filtered through $5 \mu, 2 \mu \& 0.2 \mu$ positively charged retentive filters into a pre-autoclaved and pre-cooled jacketed vessel and solution filled into aglass vial and loaded into lyophilization chamber.

\section{Optimization of Lyophilization cycle time $\mathrm{e}^{15,16,17,18}$}

\section{Differential Scanning Calorimetry (DSC)}

In order to understand the enthalpic phase transition behavior of the formulation components during lyophilization, the behavior of the formulation in solution was studied by Differential Scanning Calorimetry (DSC). Identification of the eutectic temperature and crystallization behavior of the formulation constituents was particularly important because dramatic and rapid changes in physical properties of these could affect lyophilization and the quality of the lyophilized product.

\section{Freezing}

Freezing is a critical step in the lyophilization that will affect the quality of product and also influence the primary and secondary drying process.

\section{Primary Drying Step}

After freezing next step in the lyophilisation process is primary drying. During the primary drying,the product temperature must set below the product collapse temperature and glass transition temperature. To achieve the primary drying pressure and shelf temperature are required to be controlled. To ensure completion of primary drying, before going to secondary drying, to avoid any product melt back. A gas bleed system in the instrument maintained the desired pressure during the cycle.

\section{Secondary Drying Step}

Secondary drying involves desorption of adsorbed water from the product. In secondary drying, very less amount of bound water present in the formulation. Moisture content present in the secondary drying which affects the product stability and self-life of thedrug product. Secondary drying is the slower process as compared to primary drying. Desired moisture content at the end of secondary drying to ensure residual moisture content below $4 \%$.

\section{Compatibility study with reconstitution fluids}

Para-Aminosalicylate sodium Lyophilized Powder for Infusion were reconstituted with $500 \mathrm{ml}$ of sodium chloride injection IP $0.9 \% \mathrm{w} / \mathrm{v} \& 500 \mathrm{ml}$ of Dextrose injection IP $5 \% \mathrm{w} / \mathrm{v}$. The reconstituted solutions were kept at $25^{\circ} \pm 2^{\circ} \mathrm{C} / 60 \% \mathrm{RH} \pm 5 \% \mathrm{RH} \&$ stability was evaluated at Initial \& after $24 \mathrm{hrs}$.

\section{Accelerated stability studies}

The stability studies were performed as per ICH guidelines Q1A (R2). The accelerated stability studies were performed at the temperature of $40^{\circ} \pm 2^{\circ} \mathrm{C} / 75 \% \mathrm{RH} \pm 5 \% \mathrm{RH}$ for a time period of 6 month. Various evaluation parameter wasanalyzed during stability studies such as Description, Reconstitution time, Clarity of solution, $\mathrm{pH}$, 
Particulate Matter, Related Substances (Impurities) By HPLC, Water Karl Fischer method, BET, Assay of ParaAmino Salicylate Sodium (By HPLC).

\section{Results and Discussion}

\section{Drug- Excipients compatibility study}

Drug- Excipients compatibility studywas performed at condition $40^{\circ} \mathrm{C} \pm 2{ }^{\circ} \mathrm{C} / 75 \% \mathrm{RH} \pm 5 \% \mathrm{RH}$ and $25^{\circ} \pm 2^{\circ} \mathrm{C} / 60 \% \mathrm{RH} \pm 5 \% \mathrm{RH}$ for the time period of 15 days and 1 month. The result shows that there are no physical $\&$ chemical changes or interaction between drug and excipients were observed. But, from the above observation, it is clear that sodium metabisulphite increases the percentage of impurity found that $0.12 \%$, $0.15 \%, 0.06 \%, 0.09 \%$ where the limitation is NMT $0.10 \%$ (m-aminophenol related substances). However, the composition of API with sodium sulphitereduces the impurities. Based on these studies, the excipients which are compatible with Sodium AminosalicylateDihydrate are evaluated for the formulation development. Result obtained during compatibility studies were mention on Table 1. Graphical representation of compatibility studies was shown in figure 1 .

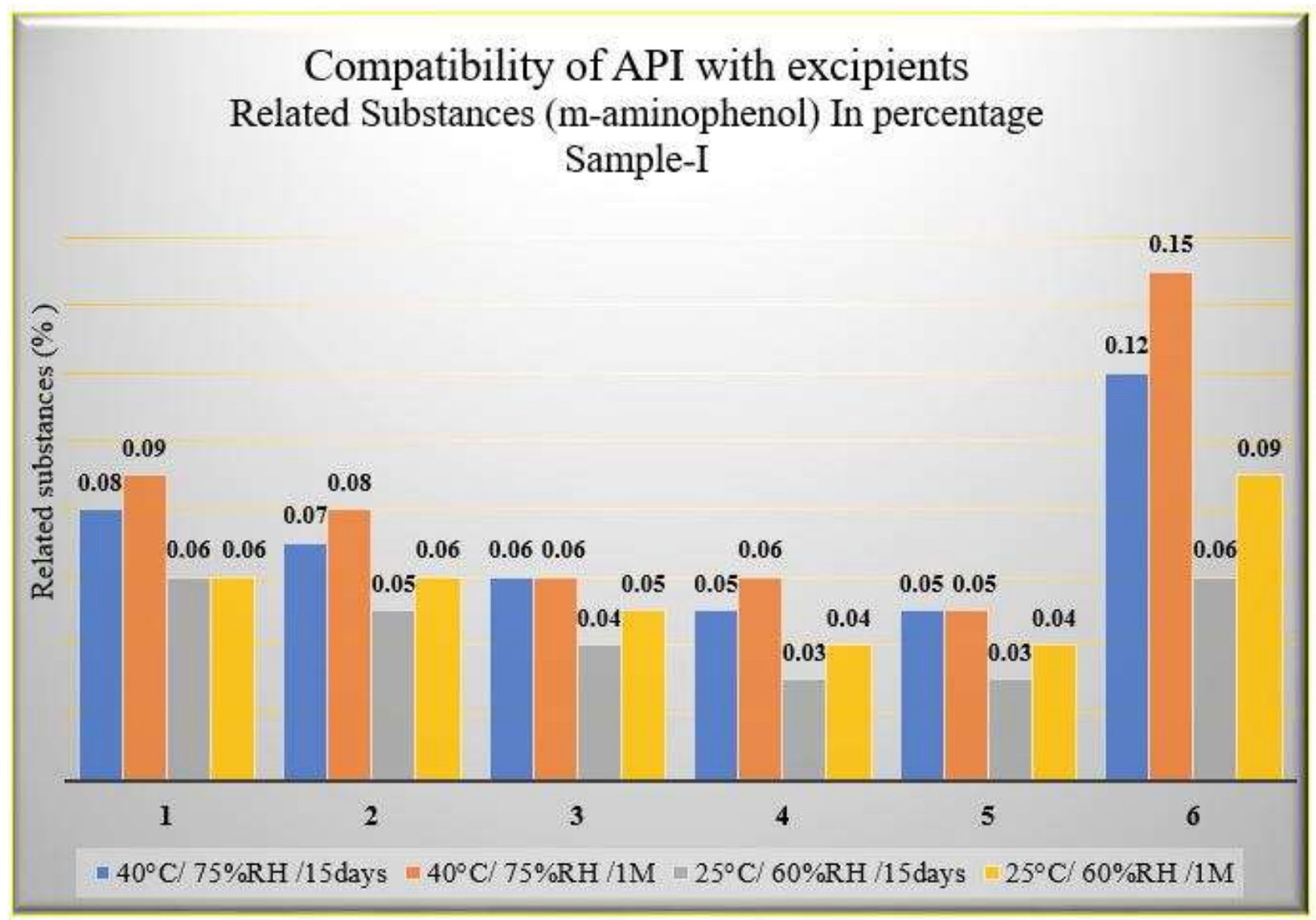

Figure 1.Graphical representation of drug- excipients compatibility study 
Table 1.Observed data during drug- excipients compatibility study

\begin{tabular}{|c|c|c|c|c|c|c|}
\hline \multicolumn{7}{|c|}{ Related Substances (In \% w/w m-aminophenol NMT 0.10\%) } \\
\hline \multirow{2}{*}{$\begin{array}{l}\text { S. } \\
\text { No }\end{array}$} & Composition details & \multirow{2}{*}{$\begin{array}{c}\text { Initial } \\
\text { Observation }\end{array}$} & \multirow{2}{*}{$\begin{array}{c}40^{\circ} \mathrm{C} / \\
75 \% \mathrm{RH} \\
/ 15 \text { days }\end{array}$} & \multirow{2}{*}{$\begin{array}{c}40^{\circ} \mathrm{C} / \\
75 \% \mathrm{RH} \\
/ 1 \mathrm{M}\end{array}$} & \multirow{2}{*}{$\begin{array}{c}25^{\circ} \mathrm{C} / \\
60 \% \mathrm{RH} \\
/ 15 \text { days }\end{array}$} & \multirow{2}{*}{$\begin{array}{c}25^{\circ} \mathrm{C} / \\
60 \% \mathrm{RH} \\
/ 1 \mathrm{M}\end{array}$} \\
\hline & Drug \& Excipient & & & & & \\
\hline 1. & Para-Amino Salicylate Sodium & $\begin{array}{c}\text { Found to be a clear } \\
\text { colorless Solution }\end{array}$ & 0.08 & 0.09 & 0.06 & 0.06 \\
\hline 2. & $\begin{array}{l}\text { Para-Amino Salicylate Sodium + } \\
\text { Sodium Chloride }\end{array}$ & $\begin{array}{l}\text { Found to be a clear } \\
\text { colorless Solution }\end{array}$ & 0.07 & 0.08 & 0.05 & 0.06 \\
\hline 3 & $\begin{array}{c}\text { Para-Amino Salicylate Sodium + } \\
\text { Disodium Edetate }\end{array}$ & $\begin{array}{l}\text { Found to be a clear } \\
\text { colorless Solution }\end{array}$ & 0.06 & 0.06 & 0.04 & 0.05 \\
\hline 4 & $\begin{array}{l}\text { Para-Amino Salicylate Sodium + } \\
\text { Sodium Sulphite }\end{array}$ & $\begin{array}{l}\text { Found to be a clear } \\
\text { colorless Solution }\end{array}$ & 0.05 & 0.06 & 0.03 & 0.04 \\
\hline 5 & $\begin{array}{c}\text { Para-Amino Salicylate Sodium + } \\
\text { Sodium Hydroxide }\end{array}$ & $\begin{array}{c}\text { Found to be a clear } \\
\text { colorless Solution }\end{array}$ & 0.05 & 0.05 & 0.03 & 0.04 \\
\hline 6 & $\begin{array}{l}\text { Sodium Para-Amino Salicylate } \\
\text { Sodium Metabisulphite }\end{array}$ & $\begin{array}{l}\text { Found to be a clear } \\
\text { colorless Solution }\end{array}$ & 0.12 & 0.15 & 0.06 & 0.09 \\
\hline
\end{tabular}

\section{Order of addition drug-excipient study}

Result obtained for an order of addition drug with excipients it shown in Table 2. Since the processes, Method A\& B, required 45 minutes \& 20 minutes respectively for complete dissolution of Disodium EDTA, where the Method $\mathrm{C}$ is required only 8minutes for complete dissolution of Disodium EDTA and it also shows less impurity profile. Best on these result Method $\mathrm{C}$ selected for formulation development. Graphical representation of the order of addition studies was shown in figure 2.

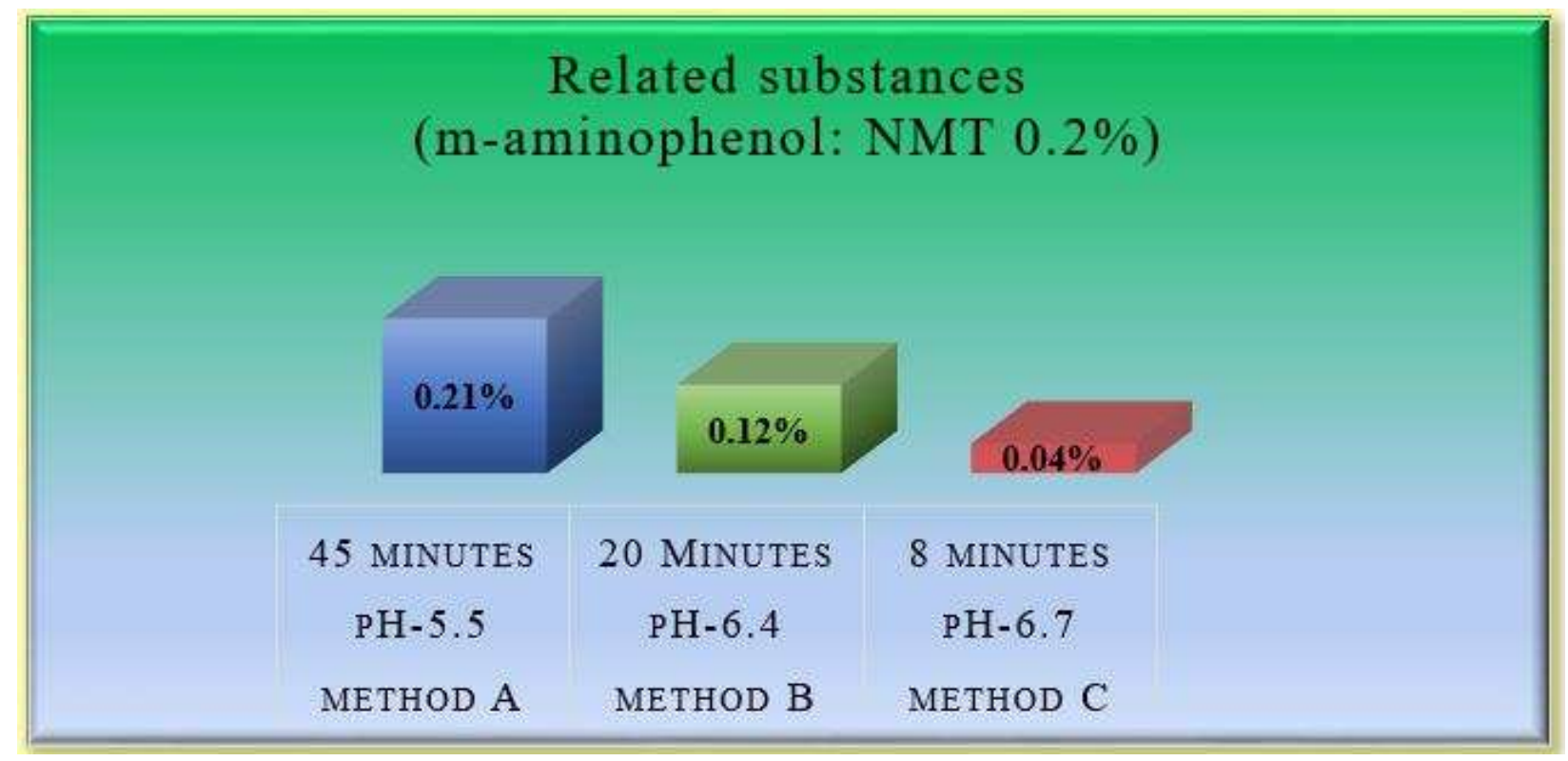

Figure 2.Graphical representation of the order of addition studies 
Table 2.observation data obtained during order of addition study

\begin{tabular}{|c|c|c|c|c|}
\hline $\begin{array}{c}\text { S. } \\
\text { No }\end{array}$ & $\begin{array}{c}\text { Method } \\
\text { No. }\end{array}$ & $\begin{array}{c}\mathbf{p H} \\
\text { (Before drug } \\
\text { addition step) }\end{array}$ & $\begin{array}{c}\text { Time required for complete } \\
\text { dissolution of Disodium EDTA }\end{array}$ & $\begin{array}{c}\text { Related Substances } \\
\text { (m-Aminophenol: NMT } \\
\mathbf{0 . 2 \%})\end{array}$ \\
\hline 1. & A & 5.5 & 45 minutes & 0.21 \\
\hline 2. & B & 6.4 & 20 Minutes & 0.12 \\
\hline 3. & C & 6.7 & 8 minutes & 0.04 \\
\hline
\end{tabular}

\section{Selection of excipients}

Based on the compatibility and order of addition result following excipients selected for development of the lyophilized product. Two trial batch (F-I, F-II) were selected for the development of lyophilized product both the batch having the same quantity and same excipient. Drug and excipient quantity were shown in Table 3.

Table 3.Composition table of drug \&excipients

\begin{tabular}{|c|c|c|c|c|c|}
\hline \multirow{2}{*}{$\begin{array}{c}\text { S } \\
\text { No. }\end{array}$} & Name of Ingredients & Function & \multirow{2}{*}{$\begin{array}{c}\text { Quantity per } \\
\text { bottle }\end{array}$} & \multicolumn{2}{|c|}{ Formulation } \\
\cline { 5 - 6 } & & F-I (100 bottles) & $\begin{array}{c}\text { F-II (100 } \\
\text { bottles) }\end{array}$ \\
\hline $\mathbf{1}$ & $\begin{array}{c}\text { Para-Amino Salicylate } \\
\text { Sodium }\end{array}$ & API & $\begin{array}{c}13.49 \\
\text { grams } / \text { bottle }\end{array}$ & $1.349 \mathrm{~kg}$ & $1.349 \mathrm{~kg}$ \\
\hline $\mathbf{2}$ & Sodium Chloride & Isotonic & 0.65 grams & $0.065 \mathrm{~kg}$ & $0.065 \mathrm{~kg}$ \\
\hline $\mathbf{3}$ & Di-sodium edetate & Antioxidant & 0.05 grams & $0.005 \mathrm{~kg}$ & $0.005 \mathrm{~kg}$ \\
\hline $\mathbf{4}$ & Sodium sulphite & Antioxidant & 0.25 grams & $0.025 \mathrm{~kg}$ & $0.025 \mathrm{~kg}$ \\
\hline $\mathbf{5}$ & Sodium Hydroxide & pH adjusts & Q. S & Q. S & Q. S \\
\hline $\mathbf{6}$ & WFI & Diluent & Q. S & Q. S & Q. S \\
\hline
\end{tabular}

\section{Differential Scanning Calorimetry (DSC)}

Differential Scanning Calorimetry (DSC) graph shows the thermal behaviour of Para-Amino Salicylate Sodiumformulation in solution was followed during both freezing and heating ramps in the temperature range of $-40^{\circ} \mathrm{C}$ and $-20^{\circ} \mathrm{C}$. DSC thermograms, obtained upon freezing the Para-Aminosalicylate sodium formulation exhibited two events between $-22.32^{\circ} \mathrm{C}$ to $-5.01^{\circ} \mathrm{C}$ i.e. from $-22.32^{\circ} \mathrm{C}$ to $-9.26^{\circ} \mathrm{C}$, A broad endotherm peak at $15.79^{\circ} \mathrm{C}$ and from $-7.31^{\circ} \mathrm{C}$ to $-5.01^{\circ} \mathrm{C}$, A sharp exotherm with a peak at $-6.18^{\circ} \mathrm{C}$. Differential scanning calorimetry graph is shown in the figure 3., and their observation of differential scanning calorimetry thermogram mentioned in table 4.

Table 4. Observation of differential scanning calorimetrythermogram

\begin{tabular}{|c|c|c|}
\hline Type of analysis & Temperature $\left({ }^{\circ} \mathrm{C}\right)$ & Description of events \\
\hline \multirow{2}{*}{$\begin{array}{c}\text { Differential Scanning } \\
\text { Calorimetry }\end{array}$} & From $-22.32^{\circ} \mathrm{C}$ to $-5.01^{\circ} \mathrm{C}$ & $\begin{array}{c}\text { Para-Aminosalicylate sodium formulation } \\
\text { exhibited two events. }\end{array}$ \\
\cline { 2 - 3 } & From $-22.32^{\circ} \mathrm{C}$ to $-9.26^{\circ} \mathrm{C}$ & A broad endotherm peak at $-15.79^{\circ} \mathrm{C}$. \\
\cline { 2 - 3 } & From $-7.31^{\circ} \mathrm{C}$ to $-5.01^{\circ} \mathrm{C}$ & A sharp exotherm with a peak at $-6.18^{\circ} \mathrm{C}$. \\
\hline
\end{tabular}




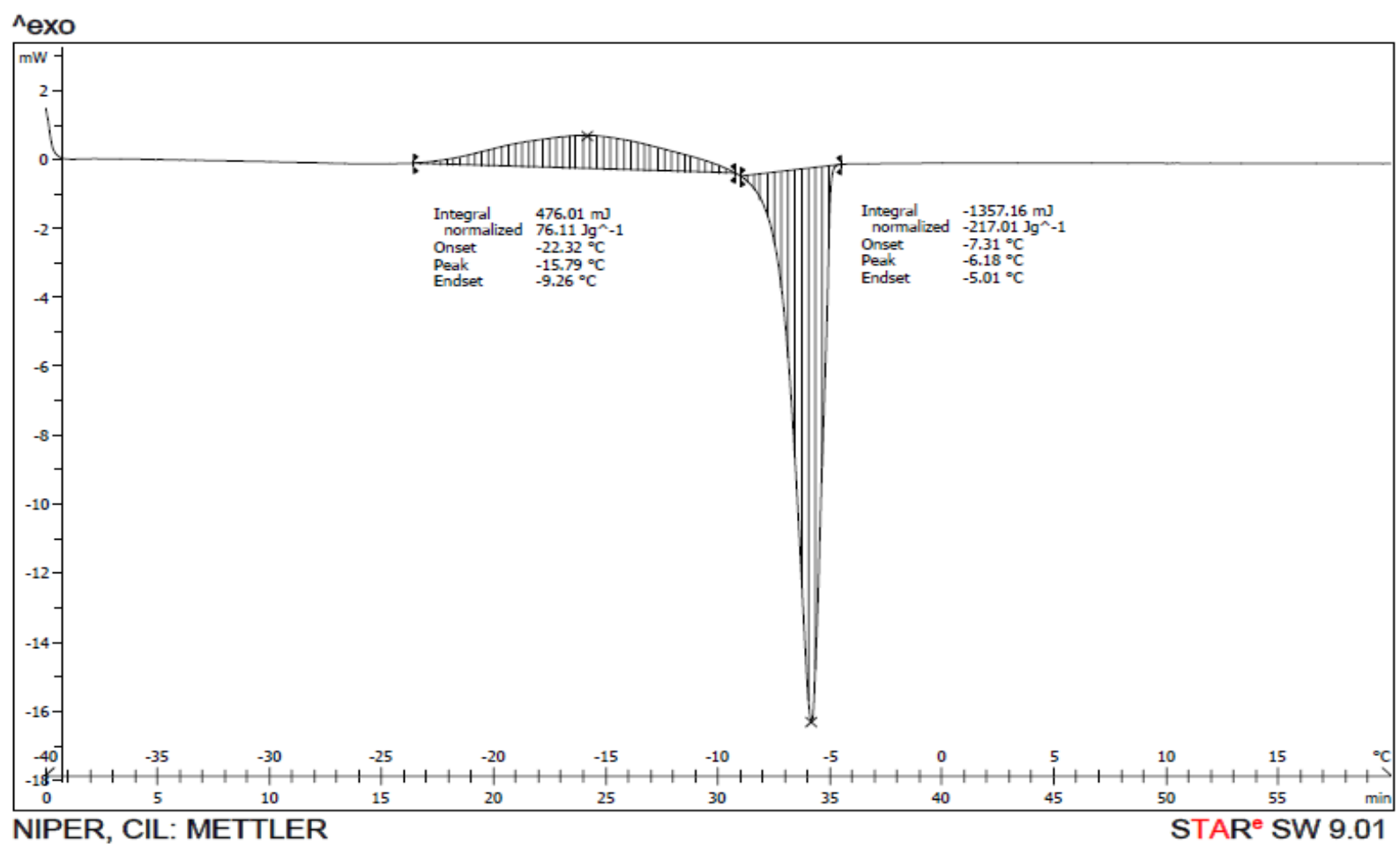

Figure 3.Differential Scanning Calorimetry (DSC)

\section{Lyophilized cycle development}

\section{Freezing}

In this cycle time take for the complete freezing of paraAminosalicylate sodium solution was found to be 13.03 hour at the particular temperature $-40{ }^{\circ} \mathrm{C}$.

\section{Primary drying}

In the primary drying For Para-Amino Salicylate Sodiumformulation, the shelf temperature was raised slowly to $-40^{\circ} \mathrm{C}$ to facilitate removal of water and majority of the primary drying was then conducted at $-25^{\circ} \mathrm{C}$. Additional primary drying was then carried out at $-20^{\circ} \mathrm{C},-10^{\circ} \mathrm{C}$ and $0^{\circ} \mathrm{C}$ to ensure completion of primary drying, while keeping the vacuum pressure (mbar 0.050). Total time required for the completion of primary drying was found to be 24 hours.

\section{Secondary drying}

For Para-Amino Salicylate Sodiumformulation, secondary drying of the product was carried out by increasing the shelf temperature from $0^{\circ} \mathrm{C}$ to $+25^{\circ} \mathrm{C}$, while keeping chamber pressure at $0.050,0.030$ millibar. Further drying was performed by increasing shelf temperature from $+35^{\circ} \mathrm{C},+45^{\circ} \mathrm{C}$ and $+50^{\circ} \mathrm{C}$ keeping chamber pressure at $0.020,0.010,0.010$ millibar to ensure low moisture content. Total time required for the completion of secondary drying was found to be 33 hours. The length of the cycle was titrated by analyzing the product for residual moisture content at the end of secondary drying to ensure residual moisture content below 4\%. Total time required for complete lyophilized cycle development was found to be 71 hours. Optimized lyophilized cycle time was given in Table. 5 . 
Table 5.Optimized lyophilized cycle

\begin{tabular}{|c|c|c|c|c|c|}
\hline Step & Stage & $\begin{array}{c}\text { Temperature } \\
\left({ }^{\circ} \mathrm{C}\right)\end{array}$ & $\underset{\text { (min) }}{\text { Ramp Time }}$ & $\begin{array}{l}\text { Drying Time } \\
\quad \text { (min) }\end{array}$ & $\begin{array}{l}\text { Vacuum } \\
\text { (mBar) }\end{array}$ \\
\hline \multirow{2}{*}{ i } & \multirow{2}{*}{ Freezing } & -40 & 120 & 540 & ------ \\
\hline & & -40 & 2 & 120 & ------- \\
\hline \multirow{4}{*}{ ii } & \multirow{4}{*}{ Primary Drying } & -25 & 60 & 300 & 0.050 \\
\hline & & -20 & 60 & 300 & 0.050 \\
\hline & & -10 & 60 & 300 & 0.050 \\
\hline & & 0 & 60 & 300 & 0.050 \\
\hline \multirow{4}{*}{ iii } & \multirow{4}{*}{$\begin{array}{l}\text { Secondary } \\
\text { Drying }\end{array}$} & 25 & 60 & 450 & 0.030 \\
\hline & & 35 & 30 & 450 & 0.020 \\
\hline & & 45 & 30 & 450 & 0.010 \\
\hline & & 50 & 30 & 480 & 0.010 \\
\hline
\end{tabular}

\section{Compatibility study with reconstitution fluids}

The reconstituted solutions were found to be a clear solution. Result for compatibility studies with reconstitution fluid was shown intable 6 . Hence, the product is stable up to 24 hrs. in $0.9 \%$ Sodium chloride, 5 $\%$ Dextrose injections\& in water for injection. There are no significance changes were found in impurity profile up to 24 hours in all type of reconstituted solutions. But, after reconstitution with $0.9 \%$ Sodium chloride\& $5 \%$ Dextrose injections, the reconstituted solution becomes hypertonic which is generally not recommended to be injected into the body at large volumes. The reconstitution with water for injection gives an isotonic solution. Water for injection is thus preferably recommended for reconstitution of Para-Aminosalicylate sodium lyophilized powder for infusion. Graphical representation of compatibility studies with reconstitution solution was shown in figure 4 .and figure 5.

Table 6.Observed data during compatibility study with reconstitution fluids

\begin{tabular}{|c|c|c|c|c|c|}
\hline \multirow[b]{3}{*}{$\begin{array}{l}\text { Batch } \\
\text { No. }\end{array}$} & \multirow[b]{3}{*}{$\begin{array}{l}\text { Reconstitution } \\
\text { Fluid }\end{array}$} & \multirow[b]{3}{*}{$\begin{array}{l}\text { Color of } \\
\text { solution }\end{array}$} & Initial & After 24 Hrs & \multirow[b]{3}{*}{$\begin{array}{c}\text { Osmolarity } \\
\text { Blood ranges } \\
\text { between } 285 \text { - } \\
310 \\
(\mathrm{mOsmol} / \mathrm{L})\end{array}$} \\
\hline & & & \multicolumn{2}{|c|}{ \% Impurity } & \\
\hline & & & $\begin{array}{l}\text { m-Aminophenol } \\
\text { NMT } 0.2 \%\end{array}$ & $\begin{array}{l}\text { m-Aminophenol } \\
\text { NMT 0.2\% }\end{array}$ & \\
\hline \multirow{3}{*}{ F-I } & $\begin{array}{c}\text { Sodium Chloride } \\
\text { Injection IP } 0.9 \% \\
\text { w/v }\end{array}$ & $\begin{array}{l}\text { Found to } \\
\text { be a clear } \\
\text { Solution }\end{array}$ & 0.10 & 0.12 & 620 \\
\hline & $\begin{array}{l}\text { Dextrose Injection } \\
\text { IP } 5 \% \mathrm{w} / \mathrm{v}\end{array}$ & $\begin{array}{l}\text { Found to } \\
\text { be a clear } \\
\text { Solution } \\
\end{array}$ & 0.09 & 0.10 & 582 \\
\hline & $\begin{array}{l}\text { Water for } \\
\text { Injection }\end{array}$ & $\begin{array}{c}\text { Found to } \\
\text { be a clear } \\
\text { Solution }\end{array}$ & 0.10 & 0.11 & 300 \\
\hline \multirow{3}{*}{ F-II } & $\begin{array}{c}\text { Sodium Chloride } \\
\text { Injection IP } 0.9 \% \\
\text { w/v }\end{array}$ & $\begin{array}{c}\text { Found to } \\
\text { be a clear } \\
\text { Solution }\end{array}$ & 0.10 & 0.11 & 640 \\
\hline & $\begin{array}{l}\text { Dextrose Injection } \\
\text { IP } 5 \% \mathrm{w} / \mathrm{v}\end{array}$ & $\begin{array}{c}\text { Found to } \\
\text { be a clear } \\
\text { Solution }\end{array}$ & 0.12 & 0.13 & 578 \\
\hline & $\begin{array}{l}\text { Water for } \\
\text { Injection }\end{array}$ & $\begin{array}{l}\text { Found to } \\
\text { be a clear } \\
\text { Solution }\end{array}$ & 0.09 & 0.10 & 295 \\
\hline
\end{tabular}




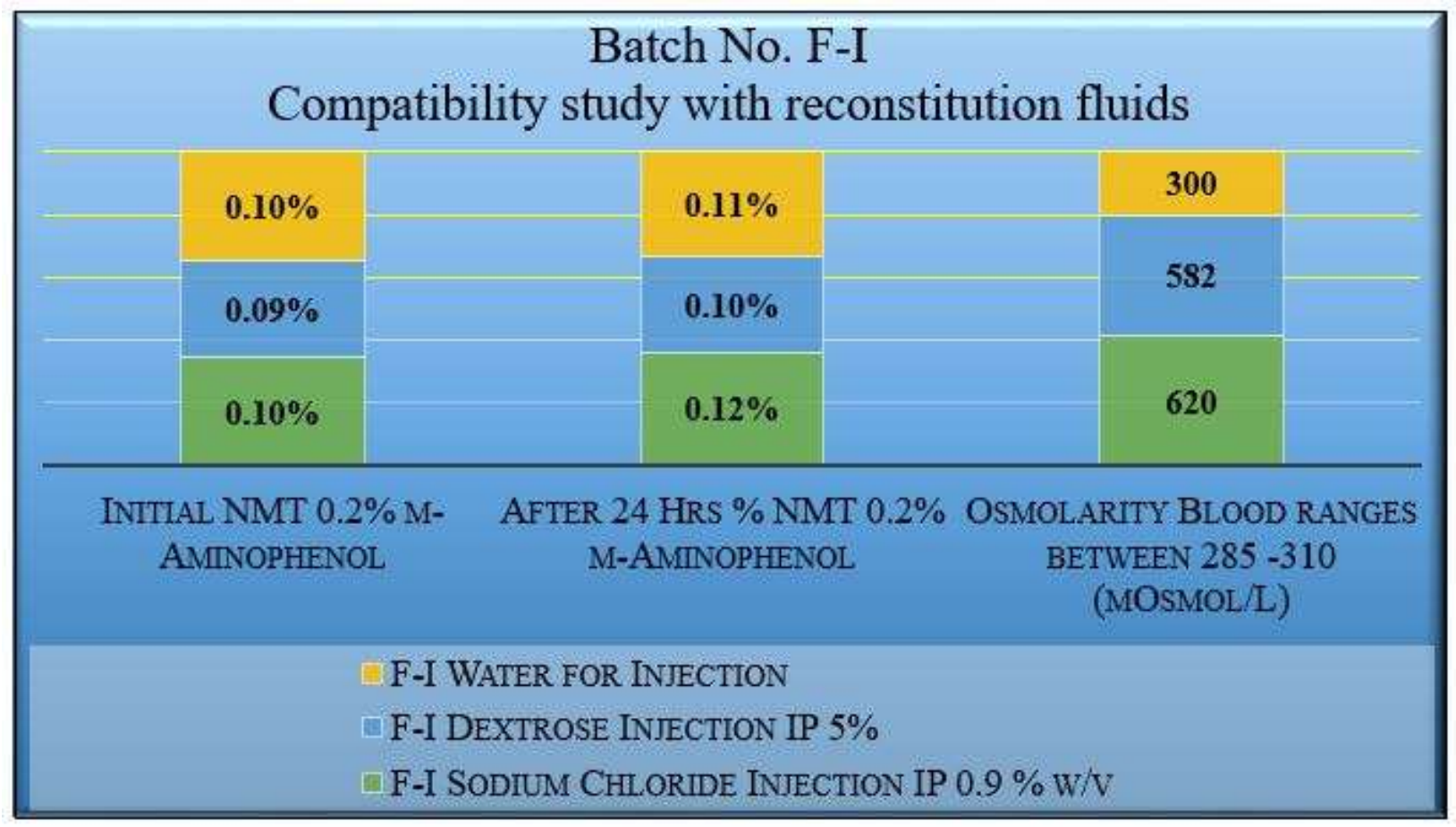

Figure 4.Graphical representation of compatibility studies with reconstitution fluids Batch No. F-I

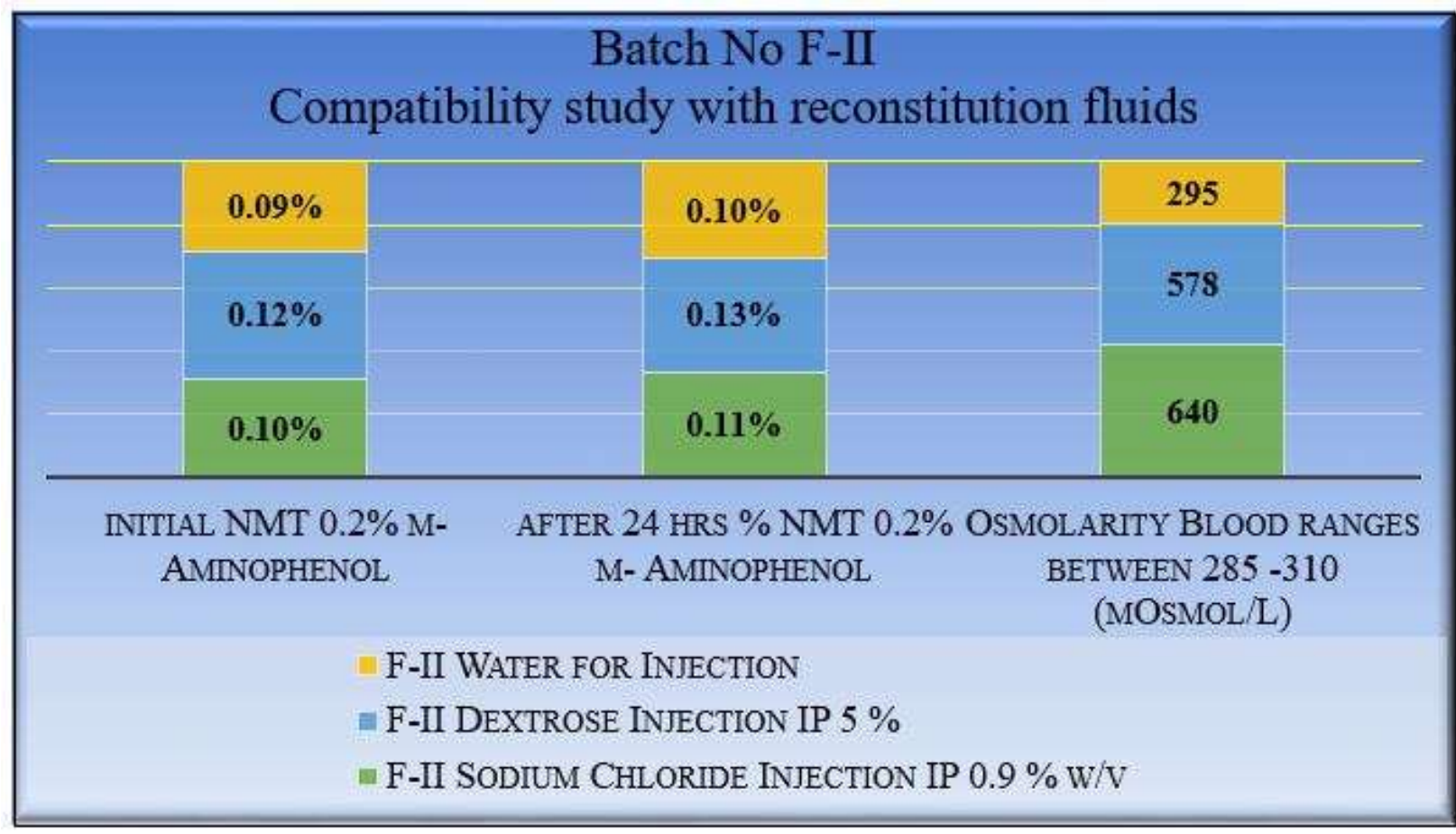

Figure 5.Graphical representation of compatibility studies with reconstitution fluids Batch No. F-II

\section{Accelerated stability studies}

Accelerated stability studies result for descriptiontest for Batch No. F-I, F-II lyophilized product initial to $6^{\text {th }}$ month accelerated stability studies result found to be within the observation limit. Result for description testmentions the table. 
Table 7.Accelerated stability result for description initial to $6^{\text {th }}$-month study

\begin{tabular}{|c|c|c|c|c|c|}
\hline \multicolumn{3}{|c|}{ Test- Description } & \multicolumn{3}{|c|}{ Accelerated Condition $\left(\mathbf{4 0} \pm \mathbf{2}^{\circ} \mathbf{C} / \mathbf{7 5 \%} \mathbf{R H} \pm \mathbf{5 \%} \mathbf{R H}\right)$} \\
\hline $\begin{array}{c}\text { Batch } \\
\text { No. }\end{array}$ & Observation & Initial & $\mathbf{2}^{\text {nd }} \mathbf{M}$ & $\mathbf{3}^{\text {rd }} \mathbf{M}$ & $\mathbf{6}^{\text {th }} \mathbf{M}$ \\
\hline F-I & $\begin{array}{c}\text { Lyophilized } \\
\text { powder white to } \\
\text { pale yellow color. }\end{array}$ & $\begin{array}{c}\text { Lyophilized } \\
\text { powder } \\
\text { founds in } \\
\text { white color. }\end{array}$ & $\begin{array}{c}\text { Lyophilized } \\
\text { powder founds } \\
\text { in white color. }\end{array}$ & $\begin{array}{c}\text { Lyophilized } \\
\text { powder founds } \\
\text { in white color. }\end{array}$ & $\begin{array}{c}\text { Lyophilized } \\
\text { powder founds } \\
\text { in white color. }\end{array}$ \\
\hline F-II & $\begin{array}{c}\text { Lyophilized } \\
\text { powder white to } \\
\text { pale yellow color. }\end{array}$ & $\begin{array}{c}\text { Lyophilized } \\
\text { powder } \\
\text { founds in } \\
\text { white color. }\end{array}$ & $\begin{array}{c}\text { Lyophilized } \\
\text { powder founds } \\
\text { in white color. }\end{array}$ & $\begin{array}{c}\text { Lyophilized } \\
\text { powder founds } \\
\text { in white color. }\end{array}$ & $\begin{array}{c}\text { Lyophilized } \\
\text { powder founds } \\
\text { in white color. }\end{array}$ \\
\hline
\end{tabular}

\section{Reconstitution time}

Reconstitution time for lyophilized product initial and 6month accelerated stability studies for both the Batch F-I, F-II result found within the observation range, where the limit is NMT 5minutes in 500ml water for injection. Result for Batch F-I, F-II were shown in table 8. Graphical representation of reconstitution time was shown in figure 6 .

Table 8. Result for reconstitution time initial and 6month accelerated stability studies

\begin{tabular}{|c|c|c|c|c|c|}
\hline \multirow{2}{*}{\multicolumn{2}{|c|}{ Test- Reconstitution time }} & \multicolumn{4}{|c|}{ Mean \pm standard deviation $(n=3)$} \\
\hline & & \multicolumn{4}{|c|}{ Accelerated Condition $\left(40^{\circ} \pm 2^{\circ} \mathrm{C} / 75 \% \mathrm{RH} \pm 5 \% \mathrm{RH}\right)$} \\
\hline $\begin{array}{l}\text { Batch } \\
\text { No. }\end{array}$ & Observation & Initial & $2^{\text {nd }} M$ & $3^{\text {rd }} \mathbf{M}$ & $6^{\text {th }} \mathrm{M}$ \\
\hline F-I & $\begin{array}{l}\text { NMT } 5 \text { minutes in } 500 \mathrm{ml} \text { of } \\
\text { water for injection. }\end{array}$ & $\begin{array}{l}51.5 \pm 1.290 \\
\text { Sec }\end{array}$ & $\begin{array}{l}52.5 \pm 1.290 \\
\text { Sec }\end{array}$ & $\begin{array}{l}55.5 \pm 1.290 \\
\quad \operatorname{Sec}\end{array}$ & $\begin{array}{l}54.5 \pm 1.290 \\
\text { Sec }\end{array}$ \\
\hline F-II & $\begin{array}{c}\text { NMT } 5 \text { minutes in } 500 \mathrm{ml} \text { of } \\
\text { water for injection. }\end{array}$ & $\begin{array}{l}52.5 \pm 1.290 \\
\text { Sec }\end{array}$ & $\begin{array}{l}51.5 \pm 1.290 \\
\mathrm{Sec}\end{array}$ & $\begin{array}{l}54.5 \pm 1.290 \\
\text { Sec }\end{array}$ & $\begin{array}{l}55.5 \pm 1.290 \\
\text { Sec }\end{array}$ \\
\hline
\end{tabular}

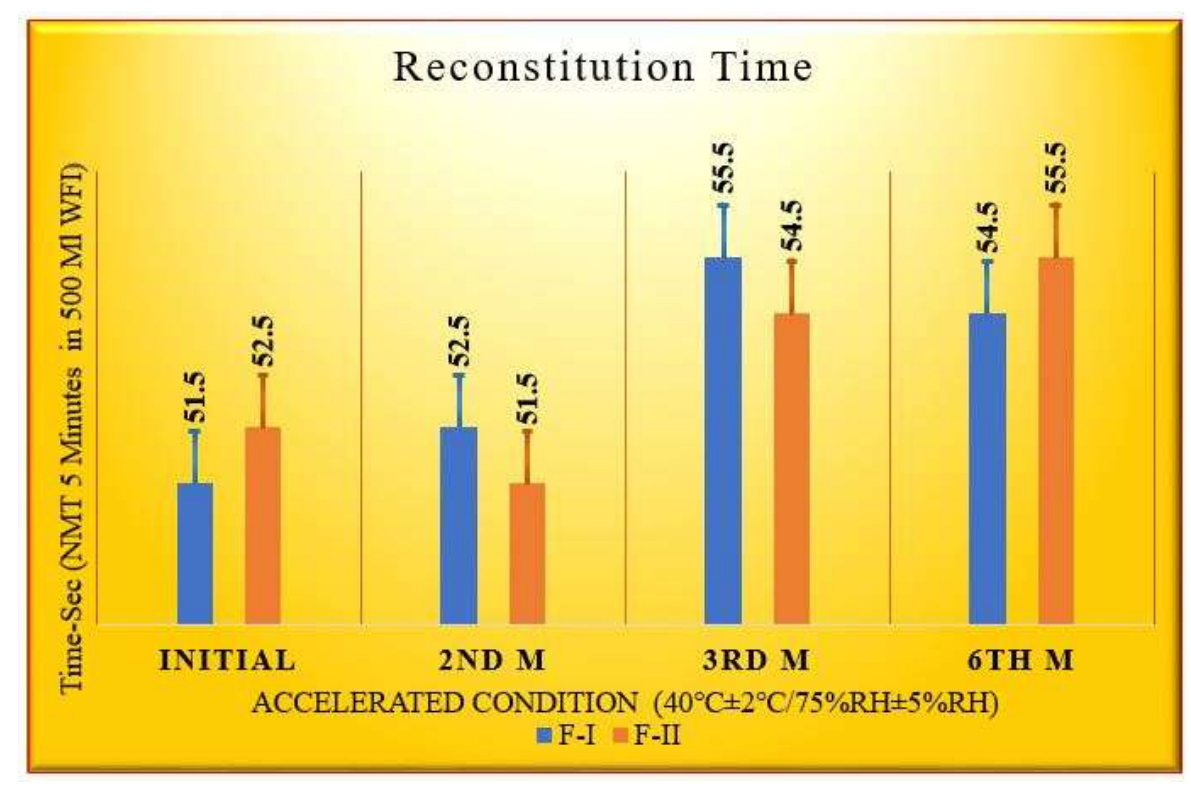

Figure 6.Graphical representation of reconstitution time Batch No. F-I, F-II 


\section{Clarity of solution}

Clarity of solution test for lyophilized product initial and 6month accelerated stability studies for both the Batch F-I, F-II result a clear solution was found and the result shown in the table.

Table 9: Result for clarity test initial to $6^{\text {th }}$ month accelerated stability

\begin{tabular}{|c|c|c|c|c|c|}
\hline \multicolumn{2}{|c|}{ Test- Clarity of solution } & \multicolumn{3}{c|}{ Accelerated Condition $\left(\mathbf{4 0} \mathbf{}^{\circ} \mathbf{2}^{\circ} \mathbf{C} / \mathbf{7 5 \%} \mathbf{R H} \pm \mathbf{5 \%} \mathbf{R H}\right)$} \\
\hline Batch No & Observation & Initial & $\mathbf{2}^{\text {nd }} \mathbf{M}$ & $\mathbf{3}^{\text {rd }} \mathbf{M}$ & $\mathbf{6}^{\text {th }} \mathbf{M}$ \\
\hline F-I & $\begin{array}{c}\text { The solution should } \\
\text { be clear. }\end{array}$ & $\begin{array}{c}\text { A clear solution } \\
\text { was found. }\end{array}$ & $\begin{array}{c}\text { A clear solution } \\
\text { was found. }\end{array}$ & $\begin{array}{c}\text { A clear } \\
\text { solution was } \\
\text { found. }\end{array}$ & $\begin{array}{c}\text { A clear } \\
\text { solution was } \\
\text { found. }\end{array}$ \\
\hline F-II & $\begin{array}{c}\text { The solution should } \\
\text { be clear }\end{array}$ & $\begin{array}{c}\text { A clear solution } \\
\text { was found. }\end{array}$ & $\begin{array}{c}\text { A clear solution } \\
\text { was found. }\end{array}$ & $\begin{array}{c}\text { A clear } \\
\text { solution was } \\
\text { found. }\end{array}$ & $\begin{array}{c}\text { A clear } \\
\text { solution was } \\
\text { found. }\end{array}$ \\
\hline
\end{tabular}

pH

$\mathrm{pH}$ test for lyophilized product initial and 6month accelerated stability studies for both the Batch No. FI, F-II result found to be within the observation range and $\mathrm{pH}$ range is from 6.5 to 8.5 and the result shown intable 10. Graphical representation of $\mathrm{pH}$ was shown in figure 7.

Table 10. Accelerated stability result for $\mathrm{pH}$

\begin{tabular}{|c|c|c|c|c|c|}
\hline \multirow{2}{*}{ Test- pH } & \multicolumn{4}{|c|}{ Mean \pm standard deviation $(\mathbf{n}=\mathbf{3})$} \\
\cline { 3 - 6 } & & \multicolumn{3}{|c|}{ Accelerated Condition $\left(\mathbf{4 0}^{\circ} \pm \mathbf{2}^{\circ} \mathbf{C} / \mathbf{7 5 \%} \mathbf{R H} \pm \mathbf{5 \%} \mathbf{R H}\right)$} \\
\hline Batch No & Observation & Initial & $\mathbf{2}^{\text {nd }} \mathbf{M}$ & $\mathbf{3}^{\text {rd }} \mathbf{M}$ & $\mathbf{6}^{\text {th }} \mathbf{M}$ \\
\hline F-I & From 6.5 to 8.5 & $7.05 \pm 0.129$ & $7.35 \pm 0.129$ & $7.85 \pm 0.129$ & $8.15 \pm 0.129$ \\
\hline F-II & From 6.5 to 8.5 & $6.75 \pm 0.129$ & $7.25 \pm 0.129$ & $7.75 \pm 0.129$ & $7.95 \pm 0.129$ \\
\hline
\end{tabular}

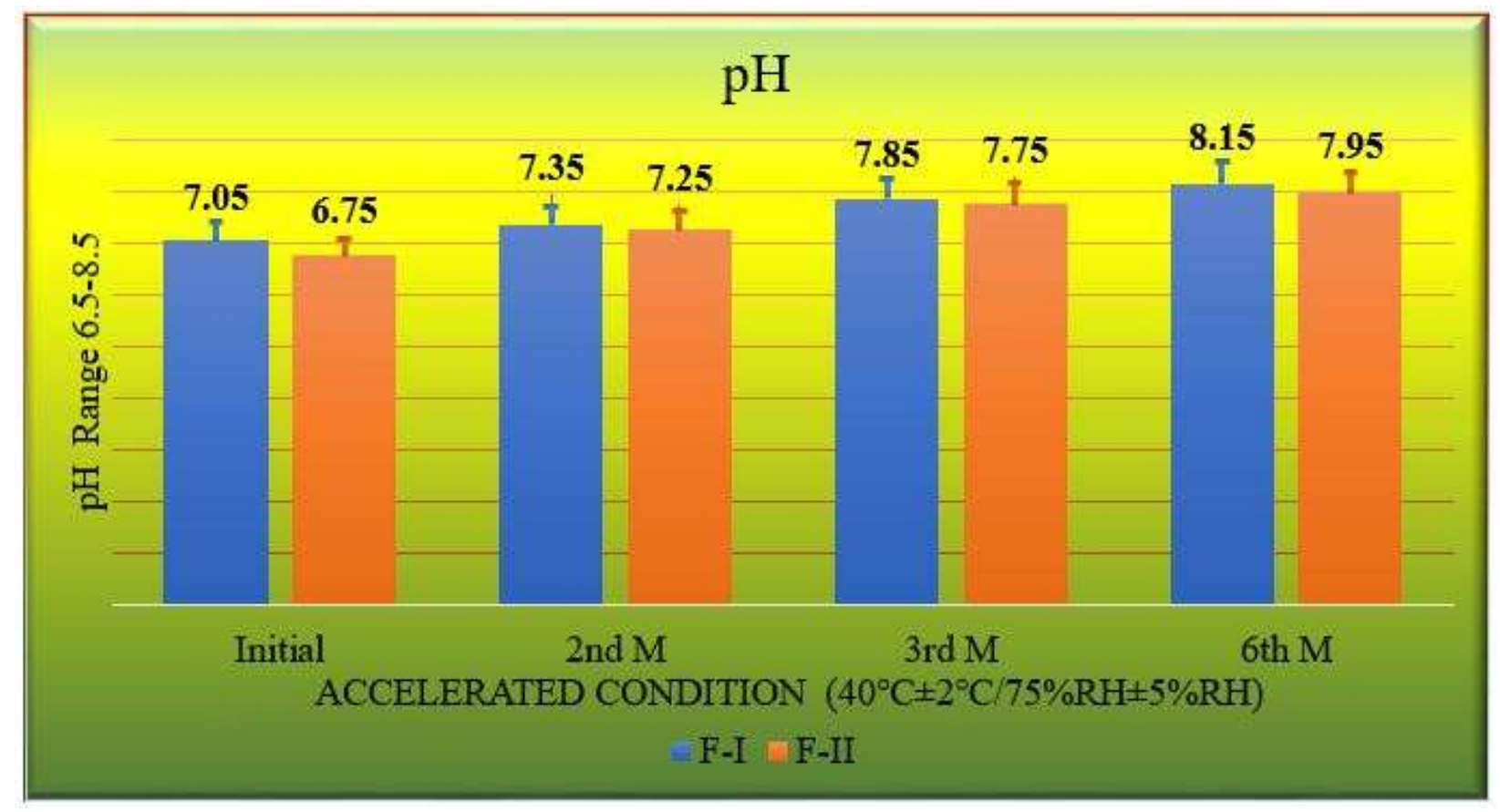

Figure 7.Graphical representation of $\mathrm{pH}$ initial to $6^{\text {th }}$-month study Batch No. F-I, F-II 


\section{Particulate matter}

Particulate matter test for lyophilized product initial to $6^{\text {th }}$ month accelerated stability studies for both the Batch F-I, F-II result for visible particles \& invisible particle found to be within the observation range and the for particulate matter shown intable 11.An invisible particle which observed during the stability study does not affect the stability of thelyophilized product.

Table 11.Accelerated stability result for particulate matter

\begin{tabular}{|c|c|c|c|c|c|c|}
\hline \multicolumn{3}{|c|}{ Test- Particulate Matter } & \multicolumn{4}{|c|}{ Accelerated Condition $\left(40^{\circ} \pm 2^{\circ} \mathrm{C} / 75 \% \mathrm{RH} \pm 5 \% \mathrm{RH}\right)$} \\
\hline $\begin{array}{c}\text { Batch } \\
\text { No }\end{array}$ & Method & Observation & Initial & $2^{\text {nd }} M$ & $3^{\text {rd }} M$ & $6^{\text {th }} M$ \\
\hline \multirow{3}{*}{ F-I } & $\begin{array}{l}\text { Visible } \\
\text { particles }\end{array}$ & $\begin{array}{l}\text { Visible particles } \\
\text { should be absent. }\end{array}$ & $\begin{array}{c}\text { No, any } \\
\text { visible } \\
\text { particles } \\
\text { observed. }\end{array}$ & $\begin{array}{l}\text { No, any } \\
\text { visible } \\
\text { particles } \\
\text { observed. }\end{array}$ & $\begin{array}{c}\text { No, any } \\
\text { visible } \\
\text { particles } \\
\text { observed. }\end{array}$ & $\begin{array}{c}\text { No, any } \\
\text { visible } \\
\text { particles } \\
\text { observed. }\end{array}$ \\
\hline & \multirow{2}{*}{$\begin{array}{l}\text { Invisible } \\
\text { particle }\end{array}$} & $\begin{array}{l}\text { Particles } \geq 10 \mu \mathrm{m} \\
\text { NMT } 25 \text { per ml }\end{array}$ & $\begin{array}{c}04 \\
\text { Particles } \\
\text { per ml }\end{array}$ & $\begin{array}{l}07 \text { particles } \\
\text { per ml }\end{array}$ & $\begin{array}{l}07 \text { particles } \\
\text { per ml }\end{array}$ & $\begin{array}{l}11 \text { particles } \\
\text { per ml }\end{array}$ \\
\hline & & $\begin{array}{c}\text { Particles } \geq 25 \mu \mathrm{m} \\
\text { NMT } 3 \text { per ml }\end{array}$ & $\begin{array}{c}00 \\
\text { Particles } \\
\text { per ml }\end{array}$ & $\begin{array}{c}00 \\
\text { particles per } \\
\text { ml }\end{array}$ & $\begin{array}{c}00 \\
\text { particles per } \\
\text { ml }\end{array}$ & $\begin{array}{c}01 \\
\text { particles per } \\
\mathrm{ml}\end{array}$ \\
\hline \multirow{3}{*}{ F-II } & $\begin{array}{l}\text { Visible } \\
\text { particles }\end{array}$ & $\begin{array}{l}\text { Visible particles } \\
\text { should be absent. }\end{array}$ & $\begin{array}{c}\text { No any visible } \\
\text { particles } \\
\text { observed. }\end{array}$ & $\begin{array}{c}\text { No any visible } \\
\text { particles } \\
\text { observed. }\end{array}$ & $\begin{array}{c}\text { No any } \\
\text { visible } \\
\text { particles } \\
\text { observed. }\end{array}$ & $\begin{array}{l}\text { No any } \\
\text { visible } \\
\text { particles } \\
\text { observed. }\end{array}$ \\
\hline & \multirow{2}{*}{$\begin{array}{l}\text { Invisible } \\
\text { particles }\end{array}$} & $\begin{array}{l}\text { Particles } \geq 10 \mu \mathrm{m} \\
\text { NMT } 25 \text { per ml }\end{array}$ & $\begin{array}{c}05 \\
\text { particles per } \\
\mathrm{ml}\end{array}$ & $\begin{array}{l}09 \text { particles } \\
\text { per ml }\end{array}$ & $\begin{array}{l}15 \text { particles } \\
\text { per ml }\end{array}$ & $\begin{array}{l}17 \text { particles } \\
\text { per ml }\end{array}$ \\
\hline & & $\begin{array}{c}\text { Particles } \geq 25 \mu \mathrm{m} \\
\text { NMT } 3 \text { per } \mathrm{ml}\end{array}$ & $\begin{array}{c}00 \\
\text { particles per } \\
\mathrm{ml}\end{array}$ & $\begin{array}{c}00 \\
\text { particles per } \\
\mathrm{ml}\end{array}$ & $\begin{array}{c}00 \\
\text { particles per } \\
\mathrm{ml}\end{array}$ & $\begin{array}{c}00 \\
\text { particles per } \\
\mathrm{ml}\end{array}$ \\
\hline
\end{tabular}

\section{Related substances (impurity)}

Related substances (impurity) for lyophilized product initial and 6month accelerated stability studies for both the Batch F-I, F-II result found to be within the observation limit. Impurity obtained stability study initial month(F-I, $0.08 \%$, F-II, 0.05\%) $6^{\text {th }}$ month (F-I, 0.16\%, F-II, 0.13\%). Where the limit is NMT $0.2 \%$ maminophenol, NMT $0.2 \%$.Result for related substance was shown intable 12. Related substances that found in the lyophilized product doesn't affect the stability of the lyophilized product. Graphical representation for related substance both Batch F-I, F-II was shown in figure 8.\& figure 9.

Table 12.Result obtained during stability study for related substances (impurity)

\begin{tabular}{|c|c|c|c|c|c|c|}
\hline \multicolumn{7}{|c|}{ Accelerated Condition $\left(40^{\circ} \pm 2^{\circ} \mathrm{C} / 75 \% \mathrm{RH} \pm 5 \% \mathrm{RH}\right)$} \\
\hline Batch No & Test & Observation & Initial & $2^{\text {nd }} M$ & $3^{\text {rd }} \mathbf{M}$ & $\mathbf{6}^{\text {th }} \mathrm{M}$ \\
\hline \multirow{3}{*}{ F-I } & \multirow{3}{*}{$\begin{array}{c}\text { Related } \\
\text { Substances } \\
\text { (Impurities) } \\
\text { By HPLC }\end{array}$} & m-Aminophenol: NMT $0.2 \%$ & $0.05 \%$ & $0.08 \%$ & $0.10 \%$ & $0.13 \%$ \\
\hline & & $\begin{array}{l}\text { Individual unidentified } \\
\text { impurity: NMT } 0.2 \%\end{array}$ & $0.01 \%$ & $0.05 \%$ & $0.09 \%$ & $0.12 \%$ \\
\hline & & $\begin{array}{l}\text { Total unidentified impurities: } \\
\text { NMT } 0.5 \%\end{array}$ & $0.04 \%$ & $0.08 \%$ & $0.10 \%$ & $0.13 \%$ \\
\hline \multirow{3}{*}{ F-II } & \multirow{3}{*}{$\begin{array}{c}\text { Related } \\
\text { Substances } \\
\text { (Impurities) } \\
\text { By HPLC }\end{array}$} & m-Aminophenol: NMT $0.2 \%$ & $0.08 \%$ & $0.11 \%$ & $0.14 \%$ & $0.16 \%$ \\
\hline & & $\begin{array}{l}\text { Individual unidentified } \\
\text { impurity: NMT } 0.2 \%\end{array}$ & $0.01 \%$ & $0.07 \%$ & $0.13 \%$ & $0.14 \%$ \\
\hline & & $\begin{array}{c}\text { Total unidentified impurities: } \\
\text { NMT } 0.5 \%\end{array}$ & $0.03 \%$ & $0.07 \%$ & $0.08 \%$ & $0.10 \%$ \\
\hline
\end{tabular}




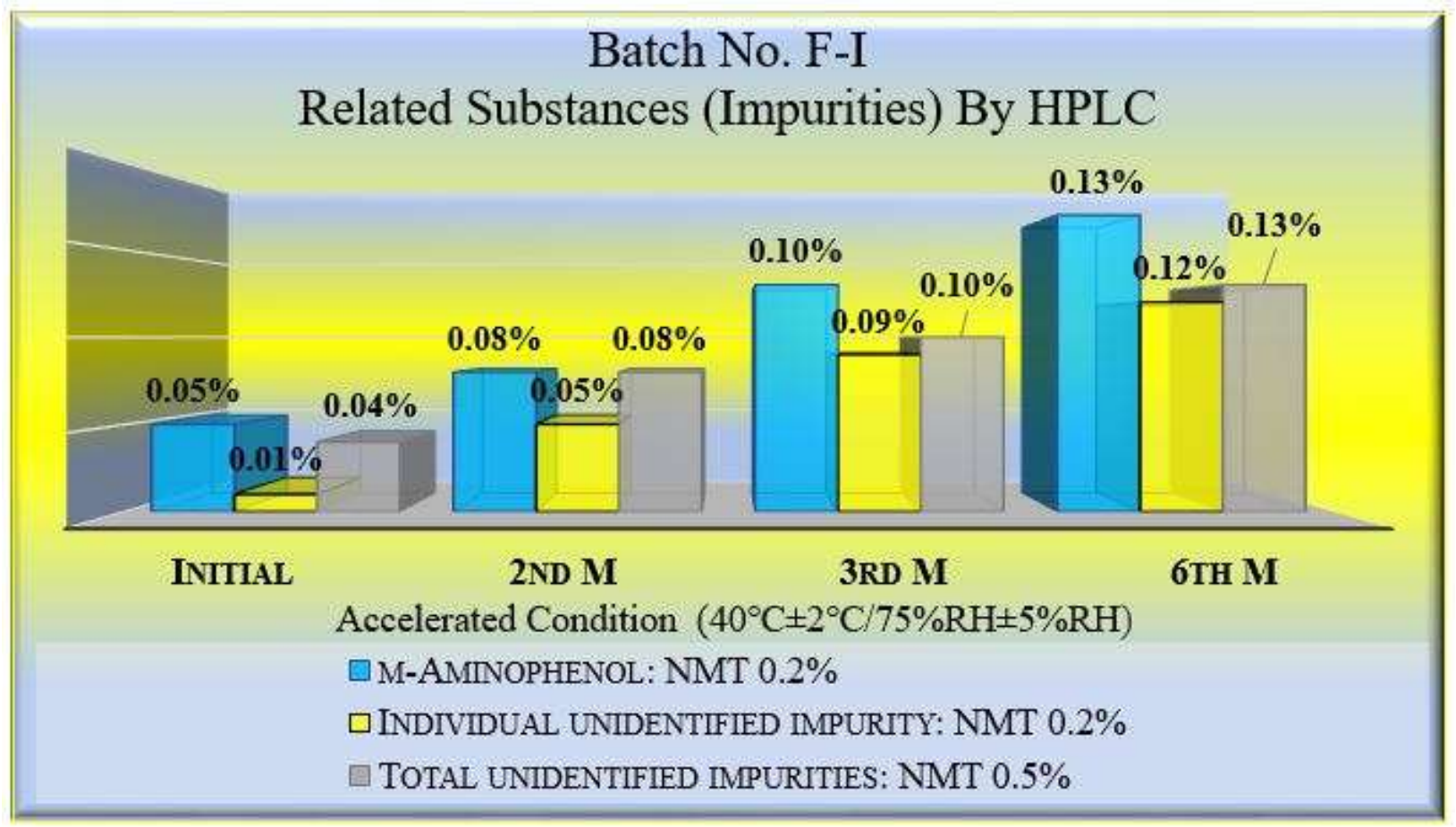

Figure 8.Graphical representation for therelated substance of Batch No. F-I shows impurity profile obtained during accelerated stability study.

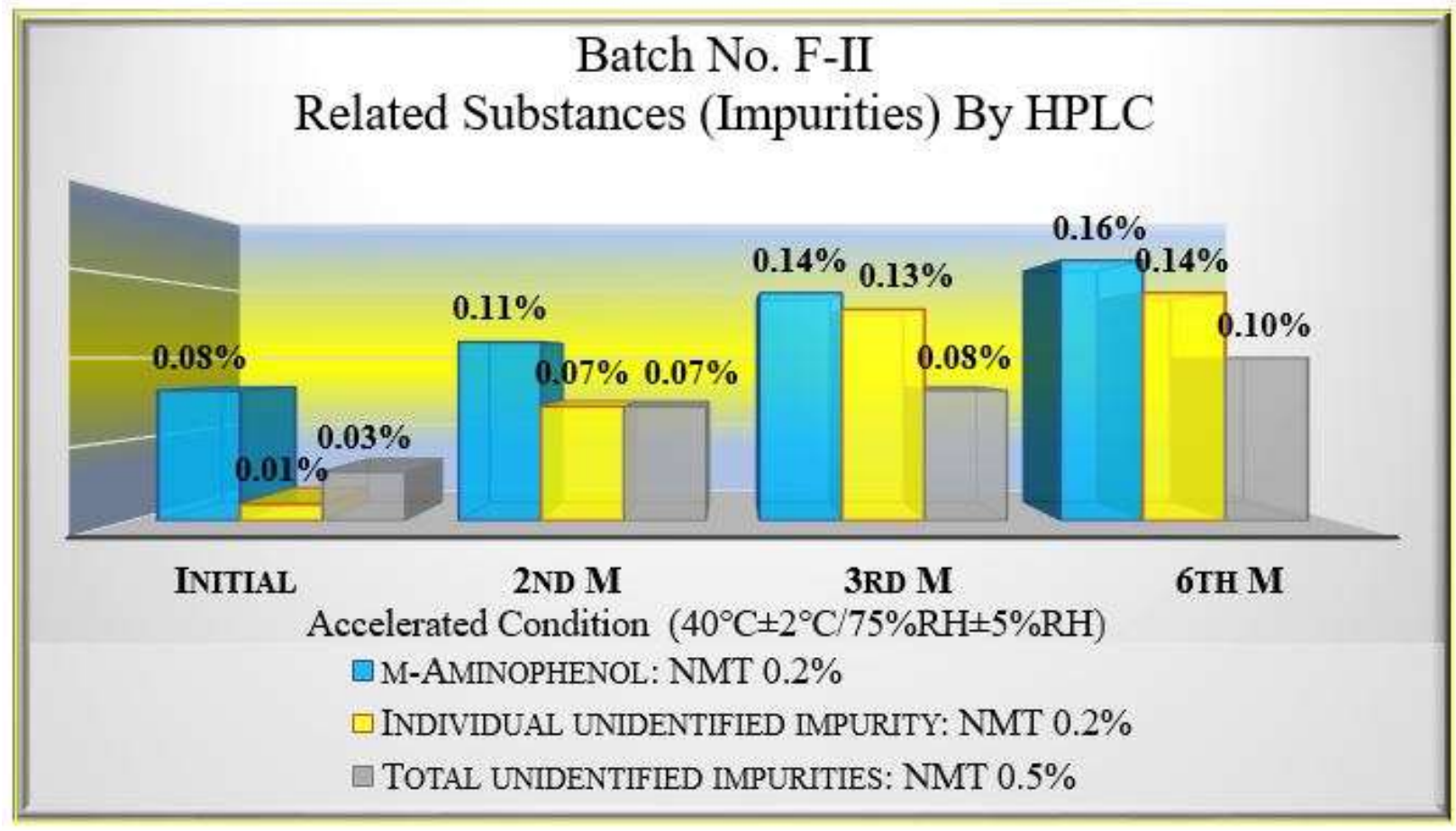

Figure 9.Graphical representation for related substance for Batch No. F-II showsimpurity profile obtained during accelerated stability study.

\section{Determination of water content}

Water content result for lyophilized product initial and 6month accelerated stability studies for both the Batch F-I, F-II result shows that initial (F-I 1.5\%, F-II 1.4\%) 6month (F-I 2.7\%, F-II 2.4\%) respectively. Result found within the limit NMT $4.0 \%$. observed data during stability test shown in table 13. Graphical representation for water content both Batch F-I, F-II was shown in figure 10. 
Table 13.Observed data for water content by Karl-Fisher method during stability study

\begin{tabular}{|c|c|c|c|c|c|c|}
\hline \multicolumn{7}{|c|}{ Accelerated Condition $\left(\mathbf{4 0}^{\circ} \pm \mathbf{2}^{\circ} \mathbf{C} / \mathbf{7 5 \%} \mathbf{R H} \pm \mathbf{5 \%} \mathbf{R H}\right)$} \\
\hline Batch No & Test & Observation & Initial & $\mathbf{2}^{\text {nd }} \mathbf{M}$ & $\mathbf{3}^{\text {rd }} \mathbf{M}$ & $\mathbf{6}^{\text {th }} \mathbf{M}$ \\
\hline F-I & $\begin{array}{c}\text { Water K. Fischer } \\
\text { method }\end{array}$ & NMT 4.0\% & $1.5 \%$ & $1.8 \%$ & $2.0 \%$ & $2.7 \%$ \\
\hline F-II & $\begin{array}{c}\text { Water K. Fischer } \\
\text { method }\end{array}$ & NMT 4.0\% & $1.4 \%$ & $1.6 \%$ & $2.2 \%$ & $2.4 \%$ \\
\hline
\end{tabular}

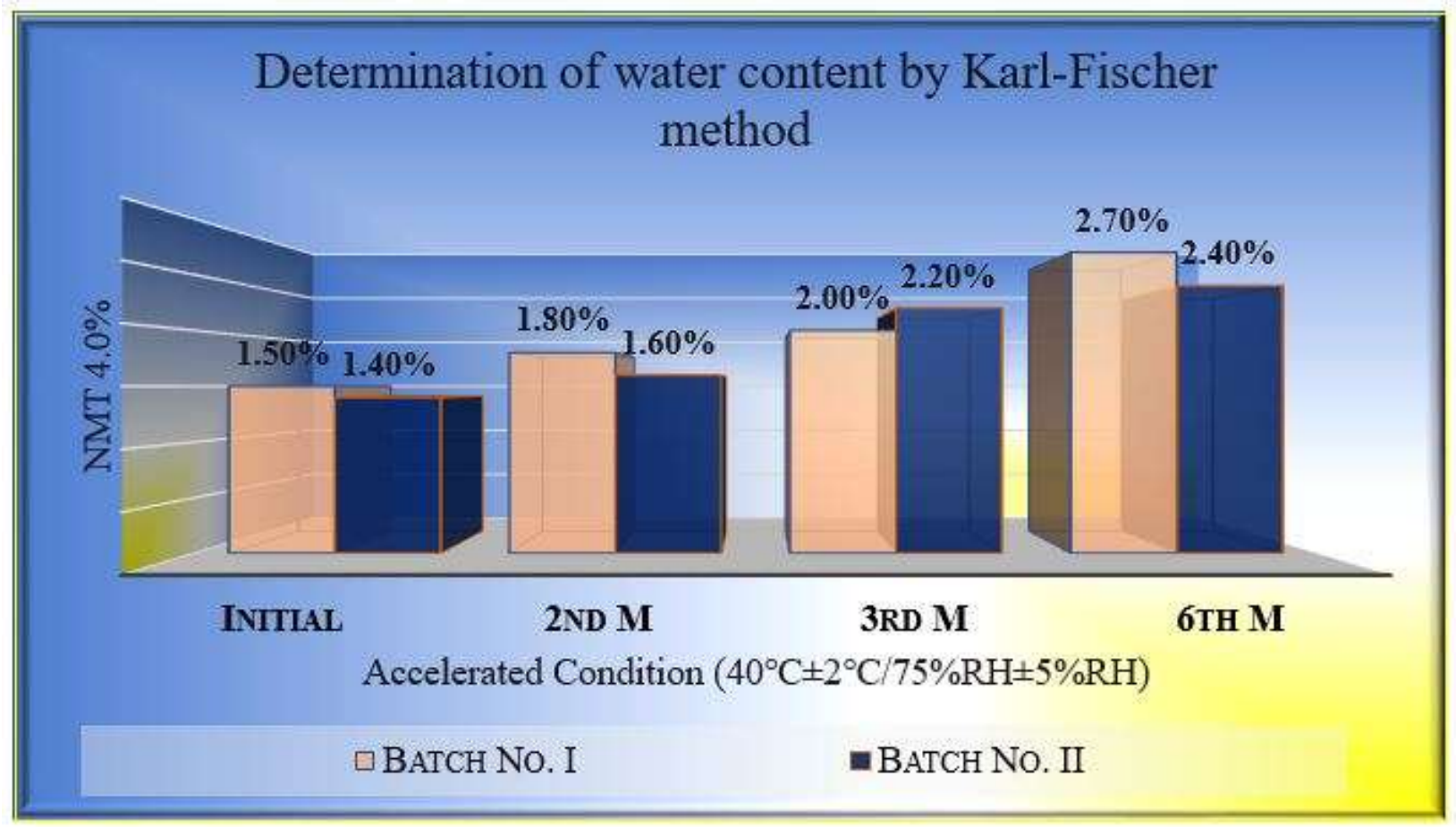

Figure 10.Graphical representation of water content observed during stability study for Batch No. F-I, FII.

\section{Bacterial endotoxins test}

Bacterial endotoxins test for lyophilized product initial and 6month accelerated stability studies for the Batch No. F-I, F-II result shows that it found to be less than $0.024 \mathrm{EU} / \mathrm{mg}$. result for bacterial endotoxins tests shown intable 14.

Table 14.Bacterial endotoxins result obtained during accelerated stability study

\begin{tabular}{|c|c|c|c|c|c|c|}
\hline \multicolumn{7}{|c|}{ Accelerated Condition $\left(\mathbf{4 0}{ }^{\circ} \pm \mathbf{2}^{\circ} \mathbf{C} / \mathbf{7 5 \%} \mathbf{R H} \pm \mathbf{5 \%} \mathbf{R H}\right)$} \\
\hline Batch No & Test & Observation & Initial & $\mathbf{2}^{\text {nd }} \mathbf{M}$ & $\mathbf{3}^{\text {rd }} \mathbf{M}$ & $\mathbf{6}^{\text {th }} \mathbf{M}$ \\
\hline \multirow{3}{*}{ F-I } & \multirow{3}{*}{ BET } & NMT 0.024EU/mg & Found less & Found less & Found less & Found less \\
& & anhydrous sodium & than 0.024 & than 0.024 & than 0.024 & than 0.024 \\
& & Aminosalicylate & EU/mg & EU/mg & EU/mg & EU/mg \\
\hline \multirow{3}{*}{ F-II } & \multirow{2}{*}{ BET } & NMT 0.024EU/mg & Found less & Found less & Found less & Found less \\
& & anhydrous sodium & than 0.024 & than 0.024 & than 0.024 & than 0.024 \\
& & Aminosalicylate & EU/mg & EU/mg & EU/mg & EU/mg \\
\hline
\end{tabular}

\section{Assay}

Assay of Para-Amino Salicylate Sodium(By HPLC) for lyophilized product initial and 6month accelerated stability studies for the Batch No. F-I, F-II result shows that reduced in the assay percentage when 
compared with initial (F-I 102.14\%, 13.7789 g, F-II 100.49\%, 13.5565g) and 6month (F-I 98.61\%, 13.3021g, FII $96.27 \%, 12.9879 \mathrm{~g}$ ) stability study. Assay $\%$ obtained during stability study found within the observation limit from $95 \%$ to $105 \%$ and $12.8155 \mathrm{~g}$ to $14.1645 \mathrm{~g} /$ bottle. Result for assay observed during stability study shown in Table 15. Graphical representation for assay\% Batch No. F-I, F-II was shown in figure 11.

Table 15. Assay result obtained during accelerated stability study

\begin{tabular}{|c|c|c|c|c|c|c|}
\hline \multicolumn{7}{|c|}{ Accelerated Condition $\left(40^{\circ} \pm 2^{\circ} \mathrm{C} / 75 \% \mathrm{RH} \pm 5 \% \mathrm{RH}\right)$} \\
\hline $\begin{array}{c}\text { Batch } \\
\text { No }\end{array}$ & Test & Observation & Initial & $2^{\text {nd }} M$ & $3^{\text {rd }} \mathbf{M}$ & $6^{\text {th }} M$ \\
\hline F-I & $\begin{array}{c}\text { Assay of } \\
\text { Aminosalicylate } \\
\text { sodium by } \\
\text { HPLC }\end{array}$ & $\begin{array}{l}\text { From } 12.8155 \text { to } \\
14.1645 \mathrm{~g} / \text { bottle, } \\
\text { from } 95 \% \text { to } 105 \\
\%\end{array}$ & $\begin{array}{l}13.7789 \mathrm{~g} \\
102.14 \%\end{array}$ & $\begin{array}{l}13.6196 \mathrm{~g} \\
100.96 \%\end{array}$ & $\begin{array}{c}13.3516 \mathrm{~g} \\
98.97 \%\end{array}$ & $\begin{array}{c}13.3021 \mathrm{~g} \\
98.61 \%\end{array}$ \\
\hline F-II & $\begin{array}{c}\text { Assay of } \\
\text { Aminosalicylate } \\
\text { sodium by } \\
\text { HPLC }\end{array}$ & $\begin{array}{c}\text { From } 12.8155 \text { to } \\
14.1645 \mathrm{~g} / \mathrm{bottle}, \\
\text { from } 95 \% \text { to } 105 \\
\%\end{array}$ & $\begin{array}{l}13.5565 \mathrm{~g} \\
100.49 \%\end{array}$ & $\begin{array}{c}13.4865 \mathrm{~g} \\
99.97 \%\end{array}$ & $\begin{array}{c}13.1875 \mathrm{~g} \\
97.75 \%\end{array}$ & $12.9879 \mathrm{~g} 96.27 \%$ \\
\hline
\end{tabular}

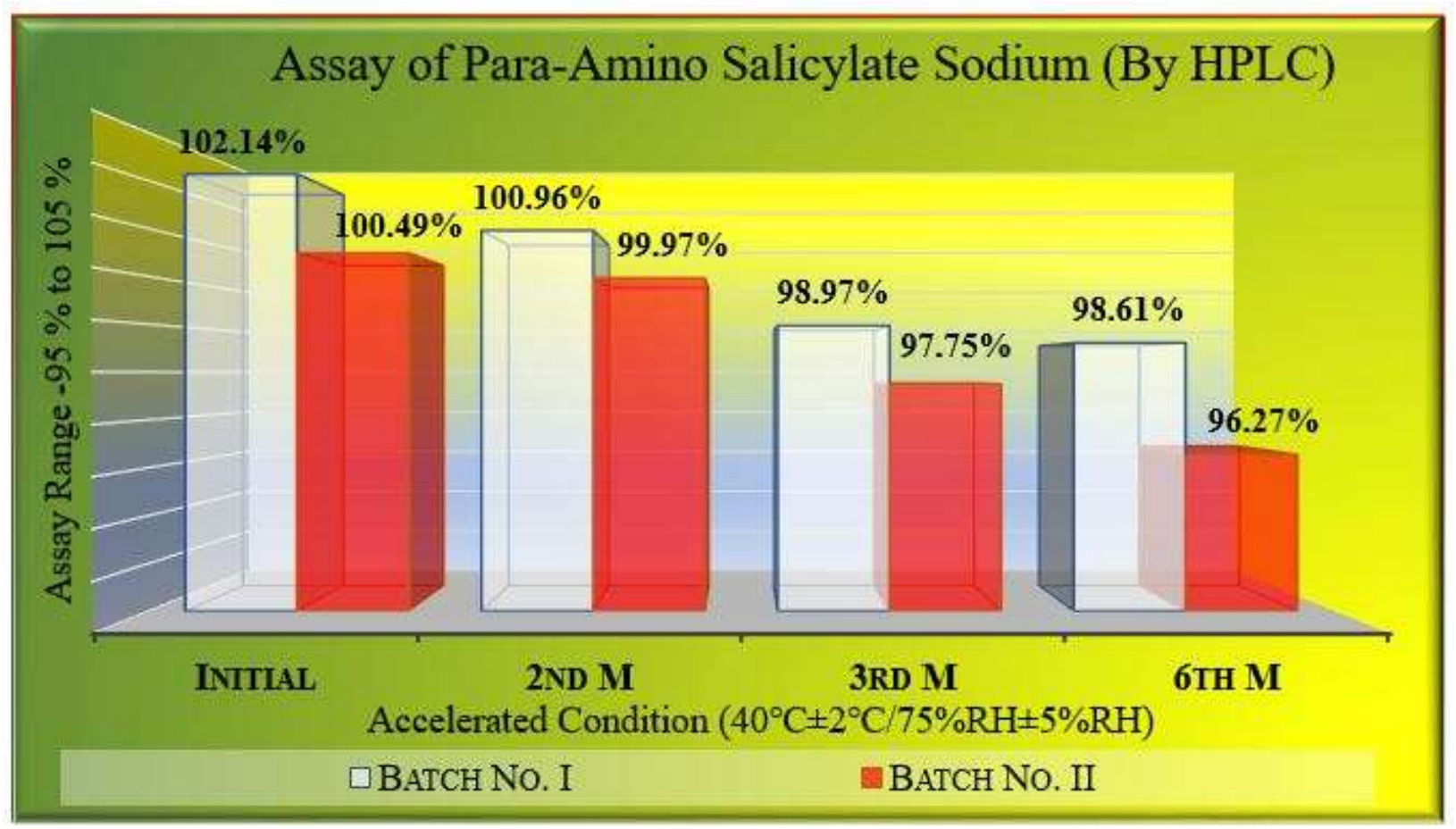

Figure 11.Graphical representation of Assay percentage obtained during accelerated stability study Batch No. F-I, F-II.

\section{Conclusion}

The final cause of research work in the field of pharmaceuticals is to develop such a product which is highly influenced and secure. Para-Amino Salicylate Sodium which is used in the treatment of multi-drug resistance tuberculosis shows unstable nature and high level of impurities in aqueous solution. Here lyophilization technique is introduced to increase self-life and stability of drug that is thermolabile and moisture sensitive in nature and generally degraded in atmospheric condition. Study of the effect of excipients over impurity level confirms that sodium metabisulphite increases the percentage of impurity, whereas sodium sulphite and other excipients reduce it significantly.Optimized lyophilized cycle time was found to be 71 hours. Results of accelerated stability study provide conclusive evidence that lyophilization technique is beneficial for 
drugs which are unstable and shows a high impurity level in an aqueous solution. Thus, from a currentstudy, it can be concluded that lyophilized injection of Para-Amino Salicylate sodium is more physically \& chemically stable and provide better therapeutic benefit in MDR-TB.

\section{References}

1. S. Sarkar and M.R. Suresh, J. Pharm. Pharm. Sci., 14, 148 (2011); doi:10.18433/J33591.

2. D. Goletti, D. Weissman, R.W. Jackson, N.M. Graham, D. Vlahov, R.S. Klein, S.S. Munsiff, L. Ortona, R. Cauda and A.S. Fauci, J. Immunol., 157, 1271 (1996).

3. F. Mariani, D. Goletti, A. Ciaramella, A. Martino, V. Colizzi and M. Fraziano, Curr. Mol. Med., 1, 209 (2001); doi:10.2174/1566524013363933.

4. G.R. Strohmeier and J.M. Fenton, Microbes Infect., 1, 709 (1999); doi:10.1016/S1286-4579(99)80072-0.

5. G. Momekov, D. Momekova, G. Stavrakov, Y. Voynikov and P. Peikov, Pharmacia, 62, 25 (2015).

6. T. Schaberg, M. Forssbohm, B. Hauer and D. Kirsten, Pneumologie, 55, 543 (2001); doi:10.1055/s2001-19106.

7. J. Rengarajan, C.M. Sassetti, V. Naroditskaya, A. Sloutsky, B.R. Bloom and E.J. Rubin, Mol. Microbiol., 53, 275 (2004); doi:10.1111/j.1365-2958.2004.04120.x.

8. S. Shetty, M.N. Hegde, P.B. Thimmaiah, S. Shetty and M. Bekal, Int. J. Res. Pharmaceutical Sci., 4, 76 (2013); doi:10.7897/2230-8407.04716.

9. $\quad$ S.S. Vishwasrao, Int. J. Pharm. Sci. Rev. Res., 29, 169 (2014).

10. S. Rautela, A. Badola, R. Verma, S. Baluni and P. Kothiyal, Eur. J. Biomed. Pharmaceut. Sci., 2, 1137 (2015).

11. T.A. Jennings, Lyophilization: introduction and basic principles. Colorado, Interpharm. Press., 1999, 412.

12. R.P. Patel, K.P. Patel, K.A. Modi and C.J. Pathak, Drugs Therapy Studies, 3, 2 (2013); doi:10.4081/dts.2013.e2.

13. M. Bouma, B. Nuijen, G. Sava, A. Perbellini, A. Flaibani, M.J. van Steenbergen, H. Talsma, J.J. Kettenes-van den Bosch, A. Bult and J.H. Beijnen, Int. J. Pharm., 248, 247 (2002); doi:10.1016/S03785173(02)00459-3.

14. Venna DP, Allam SN and Phanindra, Int. J. Sci. Res. Publications, 3, 1 (2013).

15. J.A. Searles, J.F. Carpenter and T.W. Randolph, J. Pharm. Sci., 90, 860 (2001); doi:10.1002/jps.1039.

16. J. Xiang, J.M. Hey, V. Liedtke and D.Q. Wang, Int. J. Pharm., 279, 95 (2004); doi:10.1016/j.ijpharm.2004.04.011.

17. W. Abdelwahed, G. Degobert and H. Fessi, Int. J. Pharm., 309, 178 (2006); doi:10.1016/j.ijpharm.2005.10.003.

18. A.J. Wallen, S.H. Van Ocker, J.R. Sinacola and B.R. Phillips, J. Pharm. Sci., 98, 997 (2009); doi:10.1002/jps.21491. 